\title{
Do You Like Your Teachers? A Quantitative Research on Students' Perceptions of Teacher Gender Characteristics
}

\author{
Jiaxin Chen ${ }^{1, *, \dagger}$ Keyi Zhang ${ }^{2, *, \dagger}$ Xinyu Wang ${ }^{3, *, \dagger}$ \\ ${ }^{1} X i$ 'an International Studies University, Xi'an, Shanxi, China \\ ${ }^{2}$ China Women's University, Beijing, China \\ ${ }^{3}$ University of Leeds, Leeds, UK

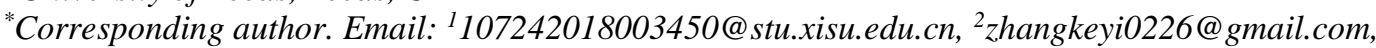 \\ ${ }^{3}$ wangxinyu431@gmail.com \\ These authors contributed equally.
}

\begin{abstract}
This paper explored Chinese high school students' preferences towards their teachers' characteristics by gender, and verified some traditional gender stereotypes in line with students' preferences. As a quantitative study, questionnaire in Likert-scale has been used and 874 valid responses are collected to identify students' preferences of their male and female teachers. The characteristics addressed by survey do partially verify some gender stereotypes and bias but not extremely obvious. Moreover, the results show that students commonly think female teachers are more considerate and sharp-eyed than male teachers, and most of students prefer male teachers teach science-related class. Furthermore, they do not enjoy old teachers' classes especially old female teachers' classes. Generally, students tend to support their same-gender teachers in classroom. All findings offer an insight into the students' gender preferences and a lack of gender education in the high school stage.
\end{abstract}

Keywords: Gender, Students' preferences, Teachers' characteristics, Chinese high school

\section{INTRODUCTION}

Gender equality plays an important role in different fields, so as in education. This research constitutes a relatively new area that has emerged from gender bias and inequalities in classroom, exploring students' preferences and views towards their teachers' gender characteristics. In addition, the current study could make a contribution to further understand high school students' mental health, and even learning outcomes through their classroom experiences with different gender teachers. Based on previous studies, gender bias exists in the classroom mainly shown by teachers' behaviours and consciousness. Many scholars evidenced that teachers' views and behaviours give both positive and negative impact on students' experiences in the classroom. However, most of those studies, for the best of our knowledge, explore gender bias/inequalities from the perspective of teachers. It is also of interest to know whether gender bias or preferences hold by students toward their teachers. To understand students' preferences, the survey, designed according to traditional gender stereotypes and gender bias, is conducted to identify students' preferences towards female and male teachers' characteristics. Therefore, it is hypothesized: (a) Gender bias toward teachers exist in students' group; (b) Female and male students have different preferences towards their female and male teachers; (c) Students' gender preferences in line with traditional gender stereotypes.

\section{LITERATURE REVIEW}

\subsection{Gender Bias and Inequalities in Classroom}

The framework of this study is rooted in gender theories, especially gender bias and inequalities which exist everywhere of human societies. In education, gender bias with inequalities intersecting with various factors among students. According to Riegle-Crumb [1], students' race, socioeconomic background, religion, and communities of where they live generally have impact on the relationship between gender and education 
experience. Evidenced by a study in UK higher education, "middle-class girls from ethnic minority backgrounds exhibit the highest participation rate, whereas White working-class boys exhibit the lowest participation rate" [2]357. Furthermore, through a study among 9 western countries, female advantages of academic outcomes were found in most of the ethnic groups and such advantage of education were commonly found in second generation as well [3]. Similarly, a study took Finnish language as a case, suggested teachers tend to give better grade to girls than boys in their language class [4]. Above all, it seems women usually give more positive performances and learning outcomes than men. However, the opposite result shows men are more likely to attend traditional STEM classes (without art) than women because female students somehow threatened by historical gender bias that men performance better than them in sciencerelated class such as math [5][6]. There are even samegender teachers who give gender bias against female students, especially at the beginning of their career, through a study towards physic teachers in German, Switzerland, and Austria [7]. To summary, gender bias and inequalities visibly exist among students and become a globally concerned issue. It also worth noting that gender bias and inequalities probably exist among teachers, which is an essential group in education with less attention in this field. Thus, this paper would give more information about teachers and would discuss gender bias and inequalities among teachers.

\subsection{Impact of Teachers' Characteristics and Performances}

Many researchers focus on education issue by exploring how teachers giving impact on students. Among those studies, students' behaviour and mental health issues are addressed by a survey about teachers' behaviours and mental problems, it finds teachers' poor preparation and stress most likely cause students' argument, fight, and stress [8]. Similarly, another research also conducted in-depth interview among math teachers. It gives result that students' feeling of belongings can be impacted by teachers' caring and their sense of identification with the value of math [9]. Moreover, some other scholars found students' characteristics effect teachers' preferences: ethic minority students commonly received negative expectation from teachers while teachers usually prefer students who are prosocial, responsible, and cooperative [10][11]. But few scholars give students' preferences towards teachers' characteristics which is a gap that current study aims to fix.

Additionally, there are only several scholars have their eyes on students' preferences in the context of gender. For example, a general idea is given that male students acting more active than female students in class when the instructor is female [12]. Besides, gender differences mostly associate with course modules such as male students usually receive positive stereotype from teachers that men are better at science-related education (i.e., math, chemistry, physical) than women, and this kind of stereotype gives women the sense of anxiety and low self-efficacy in those courses [13] [14]. However, few researchers addressed whether students would stereotype their teachers' gender in such ways. To explain, students may feel male teachers supposed to teach science-related courses rather than female and this can be a preference of students, shows students' views about teachers' gender. To summary, this paper will not only answer what kind of female/male teachers are preferred by different gender students, but also identify if the students' views to teachers' gender are influenced by teachers' characteristics such as appearances, subjects, specific occasions, and teachers' personalities.

\subsection{Gender issues in Chinese education}

Gender issues in education is wildly discussed in China as well as other countries. Some scholars suggested, with the increasing number of female students' enrollment rate, gender inequality in Chinese education is decreasing [15][16]. The fraction of reasons is national compulsory education system, promotion of gender equity, and lower education expenses [17]. In addition, with the establishment of one-child policy, gender equality is remarkably promoted in Chinese education - singleton son and singleton daughter have equal opportunity to start their education [18]. Altogether, in Chinese education, both genders generally and recently have equal access to education opportunities.

However, other scholars found gender inequality still exists. For example, Wang and Gui informed the figure of female teacher is larger than male teacher especially in primary school and middle school [19]. Thus, at the stage of mass education, a female teacherled teaching environment commonly provides better experience for female students than male students, female students' learning outcome is statistically over male students'. Hence, female students more likely get into universities [20][21]. Moreover, through a gender study about Gaokao, researchers stated gender differences exist in Gaokao: female students have higher scores than male students in language courses (English and Chinese) and overall results but show less difference in math [22]. Shao and Pang further argues the reasons behind this are complicated because their learning can be influenced by motivation, selfawareness, anxiety, etc. Above all, high school plays an important role in establishing students' gender awareness, which could impact their study and classroom experiences. It is not only about students' gender awareness towards themselves, but also towards 
their teachers. Both sides could influence their learning outcomes and classroom experiences. Therefore, a comprehensive understanding of students' gender awareness is helpful to give quality gender education, reducing the negative impact of traditional gender bias. This paper, through explore high school students' views about teachers' gender, is expected to address lacking gender education in high school stage.

\section{METHOD}

This research is quantitative, collecting data through the questionnaire and using SPSS for statistical analysis.

\subsection{Participants}

Participants were high school students randomly selected from Grade One to Grade Three in China, who were studying math, English, physical education, Chinese, political, history, geography, biology, chemistry, physical, music, computer science, and art as compulsory courses. High school students are older than primary school students to understand questions and their subjects are more unified than those of college student, and this is why high school students are chosen as research objects. Moreover, here, this paper is not going to discuss the disparity caused by regional reasons.

Table 1. Basic information of survey subjects

\begin{tabular}{lc}
\hline \multicolumn{1}{c}{ Variables } & $\begin{array}{c}\text { Sample Size } \\
\text { (Percentage) }\end{array}$ \\
\hline $\begin{array}{l}\text { Gender } \\
\text { Male }\end{array}$ & $361(41.3 \%)$ \\
Female & $513(58.7 \%)$ \\
Grade & \\
Senior One & $354(40.5 \%)$ \\
Senior Two & $335(38.3 \%)$ \\
Senior Three & $185(21.2 \%)$ \\
The ratio of male to female \\
teachers in the team \\
$\begin{array}{l}\text { The majority of teachers are } \\
\text { male }\end{array}$ \\
$\begin{array}{l}\text { The majority of teachers are } \\
\text { female }\end{array}$ \\
$\begin{array}{l}\text { There are equal numbers of male } \\
\text { and female teachers } \\
\text { Never noticed }\end{array}$ \\
\hline
\end{tabular}

\subsection{Measures}

The data used in this research were collected by questionnaire. There are a total of 39 questions in the questionnaire, which consists of basic information of survey objects and the Likert scale. Before the survey questionnaire is officially distributed, a small-scale pretest (92 respondents) was conducted and the logic and rationality of the questionnaire had been further improved based on the feedback from the survey respondents.

The basic information contains three questions related to participants' gender, grades and the gender ratio of their teachers. This part is convenient for us to better grasp the overall situation of the survey subjects and cross-analysis with the Likert scale in data analysis.

On the Likert scale, students choose between "strongly disagree" and "strongly agree" from 1 to 7 . The 7 scale gives a larger gap than the 5 scales and makes participants choose the one they prefer rather than choosing the nearby options [23]. The Likert scale consists of three parts: evaluation of female teachers (Part 1), evaluation of male teachers (Part 2), and comparison of male and female teachers (Part 3). Part 1 and Part 2 have 12 similar questions that have only one variable "gender" respectively but in a different order. Also, these similar questions do not mean they are logically complementary. For instance, if someone disagrees with "It would be better for a female teacher to teach the science-related class", it does not mean that they agree with "It would be better for a male teacher to teach the science-related class". These two parts contain questions related to students' preference towards teacher's age, appearance, personalities according to traditional gender roles, and teachers' teaching style. Moreover, it is worth mentioning that, considering that some students do not know "gender role" or "gender temperament", this study uses some statements that "sometimes I feel that a male teacher looks very feminine, which makes me feel uncomfortable". In this way, students' attitudes and requirements of teachers based on gender can be explored. Part 3 is about the comparison of male and female teachers. This part also sets up some similar questions, and uses the same method (mess up the order) of Part 1 and Part 2 to reduce the error and improve reliability. Unlike Part 1 and 2 , similar topics in this part are logically related. To explain, if someone agrees "female teachers are more sharp-eyed than male teachers in class", it seems impossible for him or her to agree "male teachers are more sharp-eyed than female teachers in class", and this is one of the factors for us to determine whether the sample is valid. Through this part, the gender bias of students towards teachers could be found out.

In general, through survey, this study tries to give a better understanding of the phenomenon of students' preferences toward teachers based on gender.

\subsection{Data Analysis}

SPSS Statistics 26 has been used for assessing descriptive statistics, and the correlations between students' attitudes and their objective factors. A total of 1144 copies of the questionnaire were distributed and 874 copies were returned effectively. 
First, this article calculates the overall mean of the scores for each item, then judges students' overall tendency for each of them. After that, through analyzing the specific score frequency on a topic, the proportion of students agreeing, neutral and disagreeing to certain issues will be shown. Also, a score of 1-3 indicates that the respondents disagree with the statement (as the score decreases, the degree of disagreement is higher), a score of 4 indicates that they hold a neutral view on the topic, and a score of 5-7 indicates that they agree with the statement (as the score increases, the degree of agreement is higher). In this way, when calculating the proportion of students who agree on a topic, it divides the number of people who choose 5-7 points by the total number of people and uses the same method to calculate the proportion of students who disagree. Finally, this paper does a cross-analysis of each question on the scale with gender to determine whether there is a significant gender difference in the degree of agreement on a topic. All cross-analysis uses the chi-square test analysis method, and under the condition of $\alpha=0.05$, the difference is statistically significant with $\mathrm{P}<0.05$, that is, $\mathrm{P}<\alpha$.

The reliability test of the Likert scale part of the questionnaire found that Cronbach's $\alpha$ value is 0.936, which is greater than 0.8 . Therefore, the Likert scale part of the questionnaire has higher reliability. As for validity, the significance level of the Bartlett test of the Likert scale part is less than the statistically significant 0.05 , that is, the variables are correlated, and factor analysis is valid. Moreover, The KMO value is 0.929 , which is greater than 0.8 . Therefore, the correlation between variables of the questionnaire is appropriate.

\section{RESULTS}

\subsection{Preferences Toward Teachers of Different Genders Exist in Students' Group}

Through the survey, it can be seen from Table 2 that $44.0 \%$ of students indicated that they are more willing to enjoy the male teachers' science-related class, while only $27.5 \%$ of them incline toward to like female teachers to teach such courses, which means, more respondents prefer male teachers to lecture in science courses.

As for teachers' age, $34.7 \%$ and $27.2 \%$ of survey objects do not like the lessons of older female teachers and older male teachers respectively. Although the difference between the figures is not huge, it could also be found that more students do not enjoy older female teacher' classes.

Besides, $44.4 \%$ of students agree that female teachers are more considerate of them, while the figure for agreeing with the statement that "male teachers are more considerate" is $27.7 \%$. This means students generally agree that female teachers care more about students than male teachers.

Table 2. Students' Preference toward teachers of different genders 1

\begin{tabular}{|c|c|c|c|c|c|c|c|}
\hline Statement & score & $\begin{array}{c}\text { Frequency } \\
\text { (Percentage) }\end{array}$ & $\begin{array}{l}\text { Averag } \\
\text { e Value }\end{array}$ & Statement & score & $\begin{array}{c}\text { Frequency } \\
\text { (Percentage) }\end{array}$ & $\begin{array}{l}\text { Averag } \\
\text { e Value }\end{array}$ \\
\hline \multirow{8}{*}{$\begin{array}{l}\text { It would be better } \\
\text { for a female } \\
\text { teacher to teach } \\
\text { the science- } \\
\text { related classes }\end{array}$} & 1 & $92(10.5 \%)$ & \multirow{8}{*}{3.85} & \multirow{8}{*}{$\begin{array}{l}\text { It would be better for } \\
\text { a male teacher to } \\
\text { teach the science- } \\
\text { related classes }\end{array}$} & 1 & $44(5.0 \%)$ & \multirow{8}{*}{4.51} \\
\hline & 2 & $74(8.5 \%)$ & & & 2 & $38(4.3 \%)$ & \\
\hline & 3 & 174(19.9\%) & & & 3 & $107(12.2 \%)$ & \\
\hline & 4 & $294(33.6 \%)$ & & & 4 & $300(34.3 \%)$ & \\
\hline & 5 & $94(10.8 \%)$ & & & 5 & $148(16.9 \%)$ & \\
\hline & 6 & $61(7.0 \%)$ & & & 6 & $95(10.9 \%)$ & \\
\hline & 7 & 85(9.7\%) & & & 7 & $142(16.2 \%)$ & \\
\hline & Total & 874(100.0\%) & & & Total & 874(100.0\%) & \\
\hline \multirow{9}{*}{$\begin{array}{l}\text { prefer an old } \\
\text { lady as my } \\
\text { teacher. It makes } \\
\text { me active and } \\
\text { much comfortable } \\
\text { in the class. }\end{array}$} & 1 & 79(9.0\%) & & \multirow{9}{*}{$\begin{array}{l}\text { I prefer an old man } \\
\text { as my teacher. It } \\
\text { makes me active and } \\
\text { much comfortable in } \\
\text { the class. }\end{array}$} & 1 & 67(7.7\%) & \multirow{9}{*}{4.17} \\
\hline & 2 & 67(7.7\%) & & & 2 & $40(4.6 \%)$ & \\
\hline & 3 & $157(18.0 \%)$ & & & 3 & $131(15.0 \%)$ & \\
\hline & 4 & 298(34.1\%) & 397 & & 4 & $340(38.9 \%)$ & \\
\hline & 5 & $130(14.9 \%)$ & 0.91 & & 5 & $129(14.8 \%)$ & \\
\hline & 6 & $59(6.8 \%)$ & & & 6 & $71(8.1 \%)$ & \\
\hline & 7 & 84(9.6\%) & & & 7 & $96(11.0 \%)$ & \\
\hline & Total & $874(100.0 \%)$ & & & Total & $874(100.0 \%)$ & \\
\hline & 1 & $49(5.6 \%)$ & \multirow{8}{*}{4.49} & & 1 & $68(7.8 \%)$ & \\
\hline \multirow{7}{*}{$\begin{array}{l}\text { From my } \\
\text { experiences, } \\
\text { female teachers } \\
\text { are more } \\
\text { considerate than } \\
\text { female teachers } \\
\text { in class. }\end{array}$} & 2 & $33(3.8 \%)$ & & \multirow{7}{*}{$\begin{array}{l}\text { From my } \\
\text { experiences, male } \\
\text { teachers are more } \\
\text { considerate than } \\
\text { female teachers in } \\
\text { class. }\end{array}$} & 2 & $70(8.0 \%)$ & \multirow{7}{*}{3.92} \\
\hline & 3 & $94(10.8 \%)$ & & & 3 & $149(17.0 \%)$ & \\
\hline & 4 & $309(35.4 \%)$ & & & 4 & $345(39.5 \%)$ & \\
\hline & 5 & $169(19.3 \%)$ & & & 5 & $131(15.0 \%)$ & \\
\hline & 6 & $92(10.5 \%)$ & & & 6 & $41(4.7 \%)$ & \\
\hline & 7 & $128(14.6 \%)$ & & & 7 & $70(8.0 \%)$ & \\
\hline & Total & $874(100.0 \%)$ & & & Total & $874(100.0 \%)$ & \\
\hline
\end{tabular}


In general, concerning Hypothesis a, although students have different preferences for teachers of different genders, the survey results do not indicate that students have obvious gender bias towards teachers.

\subsection{Students are more supportive of teachers of the same gender as themselves}

The cross-analysis of gender and scale questions show that nine statements have obvious gender differences of survey objects (Table 3). In the statement $(1),(2),(4),(5),(8),(9)$, respondents show approval and preference for their same-sex teachers. As for statement (3) and (6), more girls are willing to be taught by male teachers in science class and do not suppose the male teachers who look very feminine make them uncomfortable.

Besides, Statement (7), which has the opposite grammar to statement (8), illustrates that more boys agree that female teachers are more sharp-eyed than male teachers in class. Statement (8) indicates that more boys agree that male teachers are more sharp-eyed than female teachers in class. However, this result is not contradictory, since fewer boys are neutral on this issue. By comparing the ratio of agreeing to Statement (7) and agreeing to Statement (8) among boys and girls, it is obvious that more boys and girls agree that "female teachers are more sharp-eyed than male teachers in class".

In general, as for Hypothesis b, female and male students have a different preference towards their female and male teachers, and students are generally more supportive of teachers of the same gender as themselves. Hence, Hypothesis b is fail to be rejected.

\subsection{Students' gender preferences in line with traditional gender stereotypes}

Though survey, there is indeed a preference for teachers based on gender stereotypes. In Table 2, more students agree that male teachers are suitable for teaching science and they do not suppose female teachers come to teach science-related courses.

Table 3. Cross-analysis of gender and statement

\begin{tabular}{|c|c|c|c|c|c|}
\hline \multirow{2}{*}{ Statement } & \multirow{2}{*}{$\begin{array}{c}\text { Agree or } \\
\text { Not }\end{array}$} & \multicolumn{2}{|c|}{ Percentage (\%) } & \multirow{2}{*}{$x^{2}$} & \multirow{2}{*}{ P Value } \\
\hline & & Male & Female & & \\
\hline \multirow{2}{*}{$\begin{array}{l}\text { (1) I prefer to solve my mistakes and } \\
\text { problems with a female teacher at school. }\end{array}$} & Disagree & 35.5 & 22.3 & \multirow[b]{2}{*}{25.238} & \\
\hline & $\begin{array}{l}\text { Neutral } \\
\text { Agree }\end{array}$ & $\begin{array}{l}30.5 \\
34.0\end{array}$ & $\begin{array}{l}31.0 \\
46.7\end{array}$ & & $<0.05$ \\
\hline \multirow{3}{*}{$\begin{array}{l}\text { (2) On most occasions, I prefer male } \\
\text { teachers. }\end{array}$} & Disagree & 21.6 & 26.7 & & \\
\hline & Neutral & 35.5 & 40.4 & 20.599 & 0.002 \\
\hline & Agree & 42.9 & 32.9 & & \\
\hline \multirow{3}{*}{$\begin{array}{l}\text { (3) It would be better for a male teacher to } \\
\text { teach the science-related classes }\end{array}$} & Disagree & 24.1 & 19.9 & & \\
\hline & Neutral & 32.7 & 35.5 & 13.010 & 0.043 \\
\hline & Agree & 43.2 & 44.6 & & \\
\hline \multirow{3}{*}{$\begin{array}{l}\text { (4) I prefer to solve my mistakes and } \\
\text { problems with a male teacher at school }\end{array}$} & Disagree & 25.8 & 45.7 & & \\
\hline & Neutral & 34.6 & 33.5 & 59.052 & $<0.05$ \\
\hline & Agree & 39.5 & 20.8 & & \\
\hline \multirow{3}{*}{$\begin{array}{l}\text { (5)I feel most male teachers are more rational } \\
\text { and I am satisfied with how they solve } \\
\text { problems at school. }\end{array}$} & Disagree & 21.7 & 26.8 & & \\
\hline & Neutral & 31.6 & 37.8 & 17.200 & 0.09 \\
\hline & Agree & 46.7 & 35.4 & & \\
\hline \multirow{3}{*}{$\begin{array}{l}\text { (6) Sometimes I feel that a male teacher } \\
\text { looks very feminine, which makes me feel } \\
\text { uncomfortable in their class. }\end{array}$} & Disagree & 40.7 & 43.2 & & \\
\hline & Neutral & 30.5 & 28.3 & 14.938 & 0.021 \\
\hline & Agree & 28.8 & 28.5 & & \\
\hline \multirow{3}{*}{$\begin{array}{l}\text { (7) From my experiences, female teachers } \\
\text { are more sharp-eyed than male teachers in } \\
\text { class. }\end{array}$} & Disagree & 23.3 & 24.2 & & \\
\hline & Neutral & 35.5 & 36.3 & 15.158 & 0.019 \\
\hline & Agree & 41.2 & 39.5 & & \\
\hline \multirow{3}{*}{$\begin{array}{l}\text { (8) From my experiences, male teachers are } \\
\text { more sharp-eyed than female teachers in } \\
\text { class. }\end{array}$} & Disagree & 26.0 & 30.2 & & \\
\hline & Neutral & 37.1 & 39.4 & 14.410 & 0.025 \\
\hline & Agree & 36.9 & 30.4 & & \\
\hline \multirow{3}{*}{$\begin{array}{l}\text { (9) From my experiences, male teachers are } \\
\text { more considerate than female teachers in } \\
\text { class. }\end{array}$} & Disagree & 28.3 & 36.1 & & \\
\hline & Neutral & 37.7 & 40.7 & 16.762 & 0.01 \\
\hline & Agree & 34.0 & 23.3 & & \\
\hline
\end{tabular}


As for age, students prefer young ladies. Moreover, they believe female teachers do better in considering them than the male teachers. With regard to gender temperament, although students do not like female teachers being masculine or male teachers being feminine, they will not be extremely repulsive (Table 4).

Nevertheless, respondents have some notion breaking the gender-stereotyped. In Table 4, 31.9\% of respondents indicate they feel male teachers are more gentle than female teachers, and $37.5 \%$ of them express concern about the male teacher's appearance. As for female teachers' sense of humour, $33.6 \%$ of students agree that "female teachers are often the ones who speak sharp and humorous". Moreover, respondents generally show no objection to male teachers teaching liberal arts courses, $10.6 \%$ of whom strongly agree "It would be better for a male teacher to teach the art-related classes."

In general, as for Hypothesis c, preference based on stereotyped influence does exist but do not extreme. Simultaneously, they also have some ideas that break the gender-stereotyped.

Table 4. Students' Preference toward teachers of different genders 2

\begin{tabular}{|c|c|c|c|c|c|c|c|}
\hline Statement & score & $\begin{array}{c}\text { Frequency } \\
\text { (Percentage) }\end{array}$ & $\begin{array}{l}\text { Average } \\
\text { Value }\end{array}$ & Statement & score & $\begin{array}{c}\text { Frequency } \\
\text { (Percentage) }\end{array}$ & $\begin{array}{l}\text { Average } \\
\text { Value }\end{array}$ \\
\hline $\begin{array}{l}\text { Sometimes I feel } \\
\text { that a female } \\
\text { teacher looks very } \\
\text { masculine, which } \\
\text { makes me feel } \\
\text { curious and } \\
\text { interested in their } \\
\text { class. }\end{array}$ & $\begin{array}{c}1 \\
2 \\
3 \\
4 \\
5 \\
6 \\
7 \\
\text { Total }\end{array}$ & $\begin{array}{c}85(9.7 \%) \\
87(10.0 \%) \\
136(15.6 \%) \\
295(33.8 \%) \\
131(15.0 \%) \\
61(7.0 \%) \\
79(9.0 \%) \\
874(\%)\end{array}$ & 3.91 & $\begin{array}{l}\text { Sometimes I feel } \\
\text { that a female } \\
\text { teacher looks very } \\
\text { masculine, which } \\
\text { makes me feel } \\
\text { uncomfortable in } \\
\text { their class. }\end{array}$ & $\begin{array}{c}1 \\
2 \\
3 \\
4 \\
5 \\
6 \\
7 \\
\text { Total }\end{array}$ & $\begin{array}{c}164(18.8 \%) \\
116(13.3 \%) \\
171(19.6 \%) \\
235(26.9 \%) \\
85(9.7 \%) \\
39(4.5 \%) \\
64(7.3 \%) \\
874(100.0 \%)\end{array}$ & 3.38 \\
\hline $\begin{array}{l}\text { Sometimes I feel } \\
\text { that a male } \\
\text { teacher looks very } \\
\text { feminine, which } \\
\text { makes me feel } \\
\text { curious and } \\
\text { interested in their } \\
\text { class. }\end{array}$ & $\begin{array}{c}1 \\
2 \\
3 \\
4 \\
5 \\
6 \\
7 \\
\text { Total }\end{array}$ & $\begin{array}{c}176(20.1 \%) \\
104(11.9 \%) \\
145(16.6 \%) \\
246(28.1 \%) \\
90(10.3 \%) \\
48(5.5 \%) \\
65(7.4 \%) \\
874(100.0 \%)\end{array}$ & 3.43 & $\begin{array}{l}\text { Sometimes I feel } \\
\text { that a male teacher } \\
\text { looks very } \\
\text { feminine, which } \\
\text { makes me feel } \\
\text { uncomfortable in } \\
\text { their class. }\end{array}$ & $\begin{array}{c}1 \\
2 \\
3 \\
4 \\
5 \\
6 \\
7 \\
\text { Total }\end{array}$ & $\begin{array}{c}150(17.2 \%) \\
83(9.5 \%) \\
136(15.6 \%) \\
255(29.2 \%) \\
90(10.3 \%) \\
65(7.4 \%) \\
95(10.9 \%) \\
874(100.0 \%)\end{array}$ & 3.72 \\
\hline $\begin{array}{l}\text { It would be better } \\
\text { for a male teacher } \\
\text { to teach the art- } \\
\text { related classes }\end{array}$ & $\begin{array}{c}1 \\
2 \\
3 \\
4 \\
5 \\
6 \\
7 \\
\text { Total } \\
1\end{array}$ & $\begin{array}{c}73(8.4 \%) \\
72(8.2 \%) \\
159(18.2 \%) \\
304(34.8 \%) \\
101(11.6 \%) \\
72(8.2 \%) \\
93(10.6 \%) \\
874(100.0 \%) \\
58(6.6 \%)\end{array}$ & 4.00 & $\begin{array}{l}\text { On most of the } \\
\text { occasions, male } \\
\text { teachers are more } \\
\text { gentle than female } \\
\text { teachers and they } \\
\text { make me enjoy the } \\
\text { class. }\end{array}$ & $\begin{array}{c}1 \\
2 \\
3 \\
4 \\
5 \\
6 \\
7 \\
\text { Total } \\
1\end{array}$ & $\begin{array}{c}64(7.3 \%) \\
63(7.2 \%) \\
151(17.3 \%) \\
317(36.3 \%) \\
134(15.3 \%) \\
58(6.6 \%) \\
87(10.0 \%) \\
874(100.0 \%) \\
102(11.7 \%)\end{array}$ & 4.05 \\
\hline $\begin{array}{l}\text { From my } \\
\text { experiences and } \\
\text { point of view, my } \\
\text { female teachers } \\
\text { are often the ones } \\
\text { who speak sharp } \\
\text { and humorous }\end{array}$ & $\begin{array}{c}2 \\
3 \\
4 \\
5 \\
6 \\
7 \\
\text { Total }\end{array}$ & $\begin{array}{c}75(8.6 \%) \\
145(16.6 \%) \\
302(34.6 \%) \\
122(14.0 \%) \\
65(7.4 \%) \\
107(12.2 \%) \\
874(100.0 \%)\end{array}$ & 4.12 & $\begin{array}{l}\text { I will be very active } \\
\text { or happy in the } \\
\text { class if the male } \\
\text { teacher looks in } \\
\text { line with my } \\
\text { aesthetic }\end{array}$ & $\begin{array}{c}2 \\
3 \\
4 \\
5 \\
6 \\
7 \\
\text { Total }\end{array}$ & $\begin{array}{c}78(8.9 \%) \\
100(11.4 \%) \\
266(30.4 \%) \\
121(13.8 \%) \\
82(9.4 \%) \\
125(14.3 \%) \\
874(100.0 \%)\end{array}$ & 4.11 \\
\hline
\end{tabular}

\section{DISCUSSION}

The findings from this paper suggested that high school students do have preferences towards teachers of different genders, some of which are in line with traditional gender stereotypes, while some defy the traditional ones.

This study found gender preferences exist among high school students with an inclination for male teachers to lecture in science courses, echoing the conventional and entrenched belief of male superiority over females in math and science in the Chinese society [24]. Influenced by this stereotype, students may tend to subordinate female teachers to male teachers in the teaching of science.

Besides, students are more supportive of teachers of the same gender as themselves, which can probably be attribute to the role model effect. As Nixon and Robinson suggested when female students face uncertainty in education, the more closely they can project themselves into the role model, and the more easily they assume they can achieve what the role model will achieve, the more they will invest in their education 
[25]. Female faculty can be a better role model than male faculty for female high school students since they can connect themselves more easily with female than male faculty. It is assumed to be more accessible for students to identify themselves with same-gender teachers, resulting in match-gender preferences.

In general, students show some notions breaking the gender stereotypes, though gender preferences still exist. To illustrate, they are more inclined to agree that male teachers are gentler than female teachers, while female teachers are sharper and more humorous. Moreover, they tend to lay more emphasis on male teacher's appearance, and generally they show no objection to male teachers teaching liberal arts courses. It might be associated with the implementation of the one-child policy, as researchers suggested "the one-child policy produced more one-child households and thus removes the opportunities for parents to display gender bias, gender equality in education is readily expected" $[26]^{49}$. It is assumed that children may start to pick up the idea of gender equality with their parents discarding gender bias. As a result, students gradually defy the traditional gender stereotypes.

\section{CONCLUSION}

Overall, this study suggested that gender preferences toward teachers exist in high school students group, as students are more supportive of teachers of the same gender as themselves, such as more boys agree that males teachers are more sharp-eyed than female teachers in class. Their preferences are generally consistent with the traditional gender stereotypes, such as students prefer male teachers to lecture in science courses and consider female teachers are more considerate. However, some of their ideas break the stereotypes, such as students view male teachers as gentler than female teachers and show no objection to male teachers teaching liberal arts courses. The research points to the gender awareness of high school students and addresses lacking gender education in the high school stage. It sheds light on how teachers can better understand the mentality and preferences of male and female high students and treat them skillfully to provide a better classroom experience for all the students. It must be borne in mind that this study didn't employ interviews to investigate the deep-rooted motivation and reason for the occurrence of students' gender preferences and that considered a limited student variable of gender. Future study is hence needed to combine questionnaires with interviews to have a deeper understanding of the patterns and the causes, taking other variables such as students' age into account.

\section{REFERENCES}

[1] Riegle-Crumb, C. Gender Inequality in Education. In T. Domina, B. G. Gibbs, L. Nunn, \& A. Penner (Eds.), Education and Society, 2019, 2, pp. 41-53.

[2] Richardson, J. T. E., Mittelmeier, J., \& Rienties, B. The role of gender, social class and ethnicity in participation and academic attainment in UK higher education: an update. Oxford Review of Education, 2020 , 46(3), pp.346-362. DOI: https://doi.org/10.1080/03054985.2019.1702012

[3] Fleischmann, F., Kristen, C., Heath, A. F., Brinbaum, Y., Deboosere, P., Granato, N., Jonsson, J. O., Kilpi-Jakonen, E., Lorenz, G., Lutz, A. C., Mos, D., Mutarrak, R., Phalet, K., Rothon, C., Rudolphi, F., \& van de Werfhorst, H. G. Gender Inequalities in the Education of the Second Generation in Western Countries. Sociology of Education, 2014, 87(3), pp. 143-170. DOI: https://doi.org/10.1177/0038040714537836

[4] Krkovic, K., Greiff, S., Kupiainen, S., Vainikainen, M.-P., \& Hautamäki, J. Teacher evaluation of student ability: what roles do teacher gender, student gender, and their interaction play? Educational Research, 2014, 56(2). DOI: https://doi.org/10.1080/00131881.2014.898909

[5] Marx, D. M., Brown, J. L., \& Steele, C. M. Allport's Legacy and the Situational Press of Stereotypes. 1999.

[6] Wajngurt, C., \& Sloan, P. J. Overcoming Gender Bias in STEM: The Effect of Adding the Arts (STEAM). 2019.

[7] Hofer, S. I. Studying Gender Bias in Physics Grading: The role of teaching experience and country. International Journal of Science Education, 2015, 37(17). DOI: https://doi.org/10.1080/09500693.2015.1114190

[8] Schonert-Reichl, K. A. Social and emotional learning and teachers. Future of Children, 2017, 27(1), pp. 137-155. https://doi.org/10.1353/foc.2017.0007

[9] Maloney, T., \& Matthews, J. S. Teacher care and students' sense of connectedness in the urban mathematics classroom. Journal for Research in Mathematics Education, 2020, 51(4), pp. 399-432. https://doi.org/10.5951/jresematheduc-2020-0044

[10] Van den Bergh, L., Denessen, E., Hornstra, L., Voeten, M., \& Holland, R. W. The implicit prejudiced attitudes of teachers: Relations to teacher expectations and the ethnic achievement gap. American Educational Research Journal, 
2010, 47(2), $\quad$ pp. 497-527. https://doi.org/10.3102/0002831209353594

[11] Wentzel, K. R. Does being good make the grade? Social behavior and academic competence in middle school. Journal of Educational Psychology, 1993, 85(2), pp. 357-364. https://psycnet.apa.org/buy/1993-35423-001

[12] Aguillon, S. M., Siegmund, G. F., Petipas, R. H., Drake, A. G., Cotner, S., \& Ballen, C. J. Gender differences in student participation in an activelearning classroom. CBE Life Sciences Education, 2020, 19(2). https://doi.org/10.1187/cbe.19-030048

[13] Sunny, C. E., Taasoobshirazi, G., Clark, L., \& Marchand, G. Stereotype threat and gender differences in chemistry. Instructional Science, 2017, 45(2), pp. 157-175. https://doi.org/10.1007/s11251-016-9395-8

[14] Thomas, A. E. Gender Differences in Students' Physical Science Motivation: Are Teachers' Implicit Cognitions Another Piece of the Puzzle? American Educational Research Journal, 2017, 54(1), pp. 35-58. https://doi.org/10.3102/0002831216682223

[15] Lee, M.-H. Schooling and Industrialization in China: Gender Differences in School Enrollment. Comparative Education Review, 2014, 58(2), pp. 246-268.

https://doi.org/https://doi.org/10.1086/675380

[16] Liu, X. Chinese Women in Legal Education. Indiana Journal of Global Legal Studies, 2013, 20(2).

https://doi.org/https://doi.org/10.2979/indjglolegstu .20 .2 .1311

[17] Yang, J., Huang, X., \& Liu, X. An analysis of education inequality in China. International Journal of Educational Development, 2014, 37, pp. 2-10. https://doi.org/10.1016/j.ijedudev.2014.03.002

[18][26] Lee, M. H. The one-child policy and gender equality in education in china: Evidence from household data. Journal of Family and Economic Issues, 2012, 33(1), pp. 41-52. https://doi.org/10.1007/s10834-011-9277-9

[19][20] Wang, Weiyi, \& Gui, Q. Gaodeng jiaoyu jihui huode de xingbie bupingdeng jiqi bianhua [Gender inequalities in access to higher education and their changes A Review and Prospects of Research on Gender Differences in Higher Education Achievement]. TSINGHUA JOURNAL OF EDUCATION, 2020. 41(1).
[21] Wang, Wen, Gai, X., \& Hu, X. Ruoshi nanxing xingbie pingdeng jiaoyu zhong beihushi de wenti [Disadvantaged boys: Neglected issues in gender equality education]. Journal of Northeast Normal University (Philosophy and Social Sciences), 2010, 3, pp. 176-180.

[22] Shao, Z., \& Pang, W. Gaokao chengji xingbiechayi yanjiu de huigu yu zhanwang [A Review and Prospects of Research on Gender Differences in Higher Education Achievement]. Journal of East China Normal University (Education Science), 2016. 1 .

[23] Joshi, A., Kale, S., Chandel, S., \& Pal, D.Likert Scale: Explored and Explained. British Journal of Applied Science \& Technology, 2015. 7(4), pp. 396-403. https://doi.org/10.9734/bjast/2015/14975

[24] Tsui, M. Gender and mathematics achievement in China and the United States. Gender Issues, 2007, 24(3), pp. 1-11.

[25] Nixon, L. A., \& Robinson, M. D. The educational attainment of young women: Role model effects of female high school faculty. Demography, 1999. 36(2), pp. 185-194. 